ZOOLOGIA 28 (3): 351-356, June, 2011

doi: $10.1590 /$ S1984-46702011000300009

\title{
Macroinvertebrates associated with bryophyta in a first-order Atlantic Forest stream
}

\section{Beatriz F. J. V. Rosa', 2; Marcos V. D. da Silva'; Vívian C. de Oliveira'; Renato T. Martins ${ }^{1} \&$ Roberto da G. Alves ${ }^{1}$}

\begin{abstract}
${ }^{1}$ Laboratório de Invertebrados Bentônicos, Programa de Pós-graduação em Ciências Biológicas, Comportamento e Biologia Animal, Departamento de Zoologia, Instituto de Ciências Biológicas, Universidade Federal de Juiz de Fora. 36036-330 Juiz de Fora, Minas Gerais, Brazil.

${ }^{2}$ Corresponding author. beatrizjabour@yahoo.com.br
\end{abstract}

\begin{abstract}
This study describes the composition and structure of the benthic community associated with bryophytes in a first-order stream, located in a biological reserve of the Atlantic Forest, during two seasons. During three months of the dry season of 2007 and three months of the rainy season of 2008, samples of bryophytes attached to stones were collected randomly, along a $100 \mathrm{~m}$ stream reach. The structure of the community was analyzed through the mean density of individuals, Shannon's diversity index, Pielou's evenness, family richness, dominance index, and the percentage of Ephemeroptera, Plecoptera and Trichoptera (\% EPT). Chironomidae larvae were dominant in the two periods of study, followed by Ceratopogonidae in the rainy season, and Naididae in the dry season. The orders EPT contributed 14 families. The results showed that bryophytes constitute suitable habitat which is able to shelter an abundant and diversified benthic fauna in a small extension of the stream. This habitat provides refuge during spates, and thus minimizes downstream transport of the macroinvertebrate fauna.
\end{abstract}

KEY WORDS. Aquatic insects; lotic systems; tropical region.

Forested streams generally present high spatial heterogeneity in terms of microhabitats, water flow conditions, and existing food quality, factors that favor high diversity (BeIseL $e t$ al. 1998, SuRIANo \& FonseCA-Gessner 2004). In streams, stability of substrates usually varies and may affect the benthic fauna during spates, being one of the main factors, which determine species composition and abundance (KIKUCHI \& UIEDA 1998). Among the substrates available in streams, bryophytes constitute a distinctive habitat for colonization by different groups of invertebrates, since they accumulate organic detritus, provide substrates for algal colonization and refuge against the water current and potential predators (GALDEAN et al. 2001, TURETSKY 2003).

Studies carried out in temperate regions highlight the high richness and abundance of families of invertebrates associated with bryophytes (DEACon et al. 2001, ANDREw et al. 2003, Habdja 2004, Heino 2005, Heino \& VirTanen 2006). According to SuREN (1991), the architecture and thickness of bryophyte patches play an important role in retention of particulate organic matter, favoring the colonization of various groups of invertebrates, whose composition change along the seasons of the year due to changes in the water flow conditions (HabDija et al. 2004). In Brazil, information regarding composition, diversity and abundance of macroinvertebrates associated with these plants is still very scarce in the literature. Studies conducted in the state of São Paulo by Gorni \& Alves (2007) examined the occurrence of Naididae (Oligochaeta) in patches of moss adhered to rock substrates in the rapids of the Jacaré Pepira River. GALDEAN et al. (2001) studied the benthic fauna of streams at Serra do Cipó National Park (southeastern Brazil) and observed that moss patches constituted an important substrate for invertebrates. Costa \& Melo (2008), in a study carried out in the State Park of Intervales (São Paulo), evaluated the diversity of macoinvertebrates in three streams and four microhabitats, including mosses at the air-water interface, and attested that differences among these microhabitats were higher than among stream sites, demonstrating the importance of the variety of habitats for the maintenance of biodiversity in streams.

The present study describes the composition and structure of the benthic community associated with bryophytes in a first-order stream, located in a biological reserve of the Atlantic Forest in southeastern Brazil, during two seasons.

\section{MATERIAL AND METHODS}

The study was conducted in the Municipal Biological Reserve of Poço D'Anta, a fragment of the Atlantic Forest in secondary succession stage. The Reserve is located in the urban area 
in the city of Juiz de Fora, southeastern Brazil $\left(21^{\circ} 44^{\prime} 23^{\prime \prime}\right.$ $21^{\circ} 45^{\prime} 52^{\prime \prime} \mathrm{S}$ and $\left.43^{\circ} 18^{\prime} 29^{\prime \prime}-43^{\circ} 19^{\prime} 10^{\prime \prime} \mathrm{W}\right)$. It comprises an area of $277 \mathrm{ha}$, which shelters rich vegetation and animal species diversity, as well as springs and streams (SousA 2008).

The studied site is a first order stream located between the coordinates $21^{\circ} 44^{\prime} 36^{\prime \prime}-21^{\circ} 44^{\prime} 31^{\prime \prime} S$ and $43^{\circ} 18^{\prime} 51^{\prime \prime}$ $43^{\circ} 18^{\prime} 53^{\prime \prime} \mathrm{W}$, and at the altitude of $850 \mathrm{~m}$. It is a narrow and shallow stream with a predominantly sandy bottom and large numbers of fallen leaves and branches. The streambed also includes stones of different sizes, many of them partly covered by bryophytes.

Sampling was obtained monthly during two seasons. The first sampling occurred in the dry and cold season, in the period of July and September of 2007 (austral winter). The second sampling occurred in the rainy and warm season, during January and March of 2008 (summer) (Fig. 1).

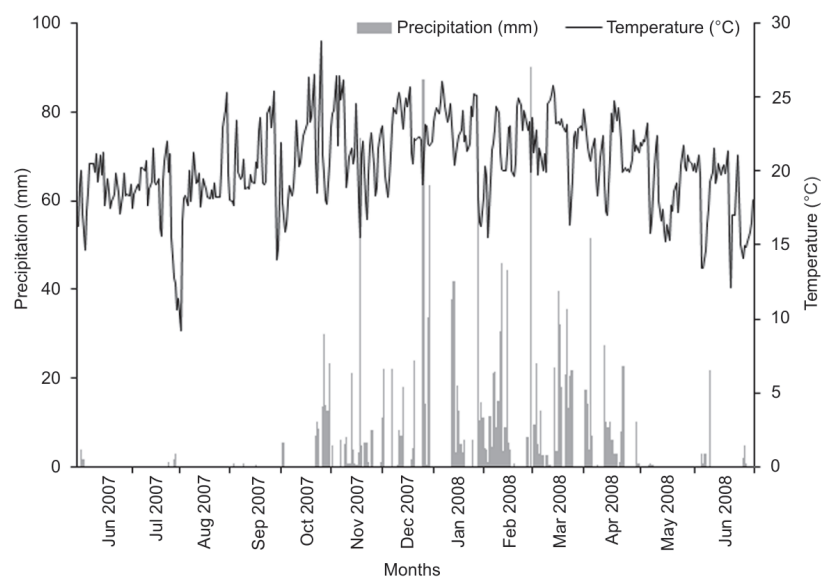

Figure 1. Monthly precipitation and average air temperature from June 2007 to June 2008 in Juiz de Fora, Brazil. The bars indicate precipitation and the line temperature. Source: Laboratório de Climatologia e Análise Ambiental, Universidade Federal de Juiz de Fora, Brazil.

Samples of bryophytes attached to stones $(25-50 \mathrm{~cm}$ diameter) protruding water surface were removed using a blade. Bryophytes were located 1-2 cm above water surface. However, in the rainy season, due to the high water level bryophytes were visibly more humid than in the dry season. In each month, two pots of $200 \mathrm{~mL}$ were filled with bryophytes from patches haphazardly selected. Two moss families, Pilotrichaceae Kindb, 1899 and Hypnaceae Schimp, 1856, and one hepatic family, Geocalycaceae H. Klinggr., 1858, were represented in the bryophyte samples.

All collections were carried out in a $100 \mathrm{~m}$ stream reach. The material collected was immediately fixed in formaldehyde solution $4 \%$. In the laboratory, samples were washed in a sieve with a $0.21 \mathrm{~mm}$ mesh size and sorted in a stereoscopic microscope. All organisms were preserved in $70^{\circ} \mathrm{GL}$ ethanol. Aquatic insects were identified at family level based on studies of McCafferty (1981), Merrit \& Cummins (1984), Fernández \& Dominguez (2001), Pes et al. (2005), and Costa et al. (2006). Oligochaeta were identified according to BRINKHURST \& MARCHESE (1989).

In order to characterize the studied stream site, water temperature, $\mathrm{pH}$, conductivity, and the dissolved oxygen were registered during the collections using a multi-sensor (Horiba U10). Mean flow velocity was obtained using the fluctuating method (MarTinell \& KRUSCHE 2007). We carried out three measurements during each sampling date for each environmental variable. The dry mass of bryophyte material was obtained after drying at $60^{\circ} \mathrm{C}$ for 48 hours.

For each sample, numerical density of each family collected (number of individuals per gram of dry mass, DM), Shannon's diversity index and Pielou's evenness were calculated according to MAGURRAN (2004). Data were averaged for each period. The family richness and the percentage of Ephemeroptera, Plecoptera and Trichoptera (\% EPT) per period were also calculated. The dominance index (DI) was obtained for each taxon, through the equation DI = Q.100. F/ $\mathrm{QQ}$ (KowNACKI 1971), where $\mathrm{Q}$ is the average number of individuals present in all the samples; $\Sigma Q$ is the total of the average quantity of all the specimens, and F the frequency of each species, when DI $>10$ (dominant), $1<\mathrm{DI}<10$ (subdominant) and DI $<1$ (adominant).

The Wilcoxon rank-sum test was used to detect whether there were significant differences $(p<0.05)$ in the Shannon's diversity, family richness, mean density of individuals, and in the $\%$ EPT between the dry and the rainy seasons. The analyses were conducted using the statistical program BioEstat 5.0 (free version).

Linear regression analysis was used to test the relationship between the response variables mean density of individuals and richness, and the predictor variable flow velocity in the two seasons (BioEstat 5.0). For this analysis, species richness, density and velocity were transformed $(\log [\mathrm{x}+1])$.

\section{RESULTS}

The reach of the studied stream presented transparent and well-oxygenated water, with low conductivity, and slightly acid water (Tab. I). The monthly average rainfall in the rainy season was higher than in the dry season, thus leading to a significant increase of the flow velocity in the rainy season $(\mathrm{Z}=2.93, \mathrm{n}=6, \mathrm{p}=0.003)$ (Tab. I).

A total of 1314 individuals distributed in 24 families were obtained in the dry season. In the rainy season, 2699 individuals and 38 families were obtained. Two families were dominant (DI > 10) during the dry season (Chironomidae and Naididae), and two during the rainy season (Chironomidae and Ceratopogonidae) (Tab. II). 
Table I. Characterization of the studied stream, located in the Poço D'Anta Municipal Biological Reserve, during the dry and the rainy season.

\begin{tabular}{lrc}
\hline & \multicolumn{2}{c}{ Mean and standard deviation } \\
\cline { 2 - 3 } & \multicolumn{1}{c}{ Dry season } & Rainy season \\
\hline Air temperature $\left({ }^{\circ} \mathrm{C}\right)$ & $19.06 \pm 1.20$ & $21.93 \pm 0.30$ \\
Water temperature $\left({ }^{\circ} \mathrm{C}\right)$ & $16.13 \pm 2.25$ & $19.16 \pm 0.28$ \\
Water speed $(\mathrm{m} / \mathrm{s})$ & $0.07 \pm 0.11$ & $0.39 \pm 0.40$ \\
Water depth $(\mathrm{cm})$ & $4.53 \pm 0.97$ & $6.73 \pm 0.75$ \\
$\mathrm{pH}$ & $6.51 \pm 0.39$ & $6.25 \pm 0.25$ \\
Conductivity $(\mu \mathrm{S} / \mathrm{cm})$ & $14.50 \pm 0.07$ & $17.00 \pm 0.01$ \\
Dissolved oxygen $(\mathrm{mg} / \mathrm{L})^{\star}$ & $10.03 \pm 0.42$ & - \\
Precipitacion $(\mathrm{mm})$ & $4.33 \pm 3.07$ & $316.00 \pm 13.57$ \\
\hline
\end{tabular}

* The values for the dissolved oxygen were registered only in the dry season.

During the rainy season, a significant increase in the mean density of individuals $(\mathrm{Z}=1.99, \mathrm{n}=6, \mathrm{p}=0.04)$ and in the family richness $(\mathrm{Z}=2.02, \mathrm{n}=6, \mathrm{p}=0.04)$ was observed. However, the Shannon's diversity index did not differ between the seasons $(Z=0.10, n=6, p=0.9)$. The orders Ephemeroptera, Plecoptera and Trichoptera (EPT) presented together relative density significantly higher during the rainy season than during the dry season $(\mathrm{Z}=2.20, \mathrm{n}=6, \mathrm{p}=0.02)$ (Tab. III).

The results of the linear regression analysis indicated that density of macroinvertebrates was affected positively by flow velocity $\left(\mathrm{R}^{2}=0.64, \mathrm{~F}_{1,4}=7.35, \mathrm{p}=0.05\right)$ (Fig. 2 ). However, there was no relationship between family richness and flow velocity $\left(\mathrm{R}^{2}=0.03, \mathrm{~F}_{1,4}=0.12, \mathrm{p}=0.74\right)$ (Fig. 3).

\section{DISCUSSION}

The results obtained indicated that bryophytes harbor more macroinvertebrates during the period of higher precipitation and flow velocity. This is the opposite pattern found in previous studies in the Neotropical region dealing with rocky substrates (FleCKer \& Feifareck 1994).

Results obtained for other kinds of substrates in streams usually show a decrease in the number of organisms during high flow, mainly in unstable substrates as sand and gravel (Amorim et al. 2004, Abílio et al. 2007, AburaYa \& CaLliL 2007). Although no data on density at other substrates are available, it is possible that bryophytes acted as refuge areas against high flow during the rainy season. This possibility is reinforced by results obtained by HABDJA et al. (2004) that found the density of macroinvertebrates in bryophytes increased non linearly with increases in current velocity, and this result was associated with an accumulation of large amounts of ultrathin particulate organic matter. As suggested by CALLISTO et al. (2001), during the rainy season, macroinvertebrates can colonize new habitats if

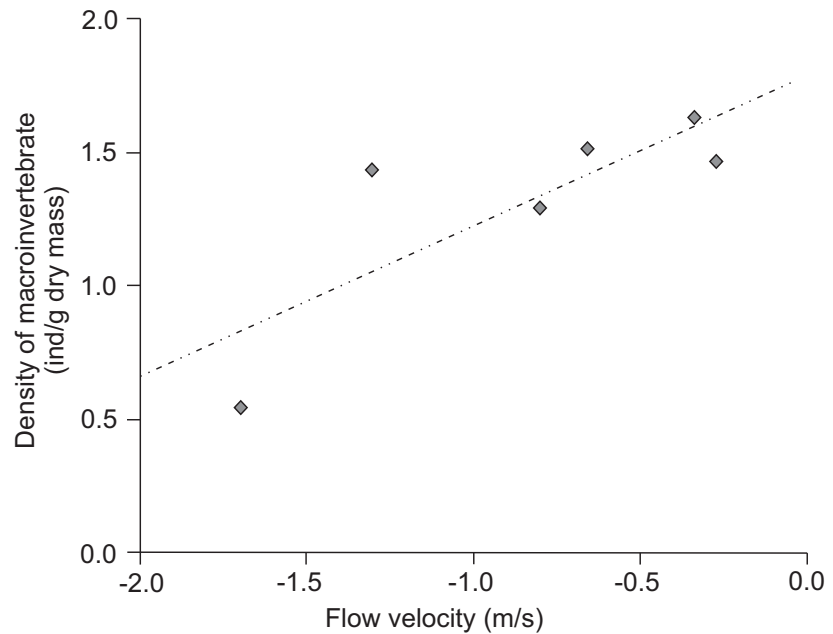

Figure 2. Effect of flow velocity on mean density of individuals (ind./g dry mass) inhabiting stream bryophytes in the Poço D'Anta Biological Reserve. The axes are in logarithmic scale.

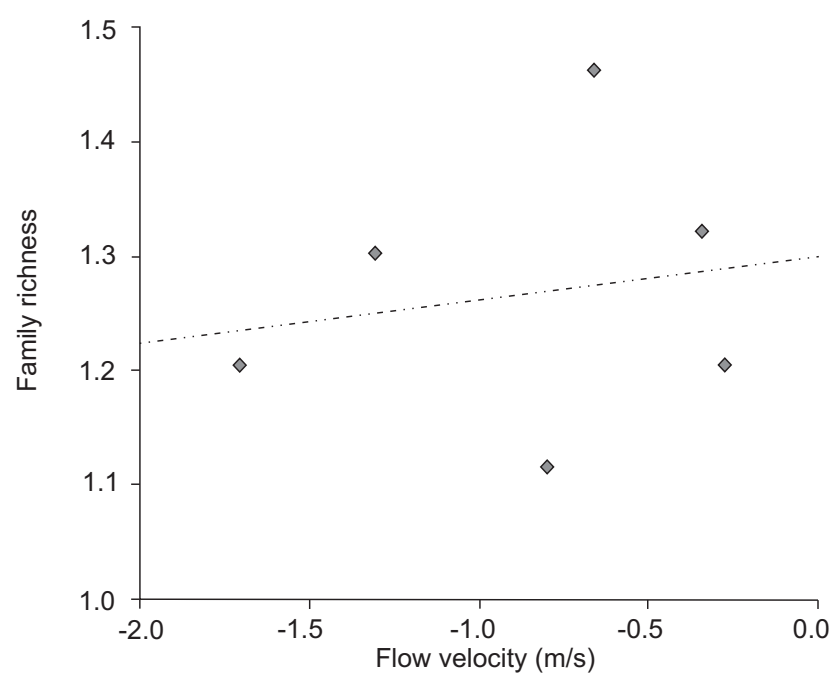

Figure 3. Effect of flow velocity on family richness of the fauna inhabiting stream bryophytes in the Poço D'Anta Biological Reserve. The axes are in logarithmic scale.

they offer high protection and shelter against the high flow, and this seems to be the case for stream bryophytes.

Chironomidae was dominant in the two seasons, followed by Ceratopogonidae in the rainy season, and Naididae in the dry season. Differences in the dominance of some taxa may occur due to changes in the water flow and associated retention of organic particles, which in turn may favor some functional groups (CRISCI-BISPO et al. 2007). Chironomidae larvae include species of most functional feeding groups, and thus are able to colonize several habitat types (Roeue et al. 2007). Besides, they 
Table II. Mean density of individuals (ind/g dry mass) and dominance index (DI) of the macroinvertebrate fauna in stream bryophytes in the Poço D'Anta Biological Reserve, during the dry and the rainy season. Dominant $(\mathrm{DI}>10)=\mathrm{DO}$, subdominant $(1<\mathrm{DI}<10)=\mathrm{SD}$ and adominant $(\mathrm{DI}<1)=\mathrm{AD}$.

\begin{tabular}{|c|c|c|c|c|c|}
\hline \multirow{2}{*}{ Order } & \multirow{2}{*}{ Family } & \multicolumn{2}{|c|}{ Dry season } & \multicolumn{2}{|c|}{ Rainy season } \\
\hline & & ind/g dry mass & $\mathrm{DI}$ & ind/g dry mass & DI \\
\hline \multirow[t]{10}{*}{ Diptera } & Chironomidae & 20.41 & DO & 41.05 & DO \\
\hline & Ceratopogonidae & 2.02 & SD & 14.38 & DO \\
\hline & Dolichopodidae & 0.23 & $A D$ & 0.43 & $A D$ \\
\hline & Dixidae & - & - & 0.02 & $A D$ \\
\hline & Empididae & - & - & 0.05 & $A D$ \\
\hline & Muscidae & - & - & 0.23 & $A D$ \\
\hline & Tabanidae & 0.05 & $A D$ & 0.10 & $A D$ \\
\hline & Tipulidae & 1.56 & SD & 1.26 & SD \\
\hline & Simuliidae & 0.02 & $A D$ & 0.15 & $A D$ \\
\hline & Stratiomyidae & 0.10 & $A D$ & 0.03 & $A D$ \\
\hline \multirow[t]{9}{*}{ Trichoptera } & Anomalopsychidae & 0.12 & $A D$ & 0.97 & $A D$ \\
\hline & Calamoceratidae & - & - & 0.05 & $A D$ \\
\hline & Helicopsychidae & - & - & 0.15 & $A D$ \\
\hline & Hydropsychidae & 0.22 & $A D$ & 0.44 & $A D$ \\
\hline & Hydroptilidae & 0.43 & $A D$ & 1.15 & SD \\
\hline & Odontoceratidae & 0.02 & $A D$ & 0.15 & $A D$ \\
\hline & Philopotamidae & - & - & 0.21 & $A D$ \\
\hline & Polycentropodidae & - & - & 0.15 & $A D$ \\
\hline & Xiphocentronidae & - & - & 0.13 & $A D$ \\
\hline \multirow[t]{3}{*}{ Ephemeroptera } & Baetidae & 0.02 & $A D$ & 0.28 & $A D$ \\
\hline & Caenidae & - & - & 0.05 & $A D$ \\
\hline & Leptophlebiidae & - & - & 0.03 & $A D$ \\
\hline \multirow[t]{2}{*}{ Plecoptera } & Gripopterygidae & - & - & 0.08 & $A D$ \\
\hline & Perlidae & 0.02 & $A D$ & 0.23 & $A D$ \\
\hline \multirow[t]{3}{*}{ Hemiptera } & Hebridae & 0.02 & $A D$ & - & - \\
\hline & Mesoveliidae & 0.05 & $A D$ & 0.05 & $A D$ \\
\hline & Veliidae & 0.12 & $A D$ & 0.13 & $A D$ \\
\hline \multirow[t]{7}{*}{ Coleoptera } & Amphizoidae & - & - & 0.03 & $A D$ \\
\hline & Curculionidae & - & - & 0.03 & $A D$ \\
\hline & Elmidae & 0.28 & $A D$ & 0.44 & $A D$ \\
\hline & Hydraenidae & 0.02 & $A D$ & 0.03 & $A D$ \\
\hline & Hydrophilidae & 0.07 & $A D$ & 0.08 & $A D$ \\
\hline & Psephenidae & 0.02 & $A D$ & - & - \\
\hline & Scirtidae & - & - & 0.13 & $A D$ \\
\hline Lepidoptera & Pyralidae & 0.07 & $A D$ & - & - \\
\hline \multirow[t]{2}{*}{ Odonata } & Calopterygidae & - & - & 0.03 & $A D$ \\
\hline & Coenagrionidae & - & - & 0.05 & $A D$ \\
\hline Megaloptera & Corydalidae & - & - & 0.03 & $A D$ \\
\hline \multirow[t]{4}{*}{ Oligochaeta } & Megadrilli & 0.05 & $A D$ & - & - \\
\hline & Enchytraeidae & 0.76 & SD & 1.85 & SD \\
\hline & Naididae & 6.48 & DO & 4.03 & DO \\
\hline & Tubificidae & 0.41 & $A D$ & 0.54 & $A D$ \\
\hline
\end{tabular}


Table III. Family richness, \%Ephemeroptera+Plecoptera+ Trichoptera (EPT), mean values for Shannon's diversity, Pielou's evenness, and density of individuals associated to stream bryophytes in the Poço D'Anta Municipal Biological Reserve, during the dry and the rainy season.

\begin{tabular}{lcc}
\hline & Dry season & Rainy season \\
\hline Family richness & 24 & 38 \\
$\%$ EPT & 2.58 & 5.89 \\
Pielou's evenness & $0.49 \pm 0.17$ & $0.42 \pm 0.15$ \\
Shannon's diversity & $1.37 \pm 0.43$ & $1.32 \pm 0.57$ \\
$\begin{array}{l}\text { Mean density (ind./g bryophyte } \\
\text { dry mass) }\end{array}$ & $33.69 \pm 2.66$ & $69.20 \pm 4.24$ \\
\hline
\end{tabular}

are considered efficient colonizers (CALLISTO et al. 2001), what probably leads to the high abundance of this family of bryophytes.

Naididae was the most common family of Oligochaeta. They are predominantly free swimmers (VERDONSCHOT 1982), what may have favored the utilization of the bryophytes as habitat by these invertebrates. Naididae was the only family representing Oligochaeta in samples of bryophytes collected in rocky substrates of rapids by GoRnI \& Alves (2007). This family was also one of the most abundant in the study carried out by SUREN (1993) in a stream in New Zealand.

Some Ceratopogonidae species are predators and feed on aquatic insect eggs. Others feed on periphyton or are omnivorous (McCafferty \& Provonsha 1983). In a tropical stream, these larvae were classified by MotTA \& Uieda (2004) as detritivorous in the rainy season, but were mostly restricted to feed on periphyton in the dry season, indicating the broad flexibility of these insects in terms of feeding habits. In addition, the larvae of this group are less selective in choosing substrate (Fidelis et al. 2008), and these factors may have favored colonization of bryophytes by these invertebrates during the rainy season.

Immature individuals of Ephemeroptera, Plecoptera and Trichoptera were represented by 14 families, indicating the importance of these insects in the composition of the benthic fauna in the bryophyte samples. Studies carried out in temperate regions also show a high contribution of EPT families to the composition of the macroinvertebrate fauna inhabiting stream bryophytes (Suren 1993, Habdja et al. 2004, Korsu 2004). Among the families found by these authors, Baetidae, Hydropsychidae, Hydroptilidae, Philopotamidae, and Polycentropodidae were also present in this study.

The results indicate that bryophytes attached to stones provide suitable habitat to shelter an abundant and diversified fauna of benthic macroinvertebrates even in a small extension of stream. In addition, bryophytes in streams are likely to act as refuge areas for benthic invertebrates during the period of increase in water flow.

\section{ACKNOWLEDGMENTS}

We would like to thank CNPq for the undergraduate fellowship to Marcos Vinícius Dias da Silva that allowed the conductions of this work. FAPEMIG provided financial support (Process CRA - APQ-01285-08). We would also like to thank Andréa Pereira L. Ponzo, of the Botany Department (ICB/UFJF) for the identification of the bryophyte families.

\section{LITERATURE CITED}

AbíLIO, F.J.P.; T.L.M. Ruffo; A.H.F.F. Souza; H.S. Florentino; E.T.O. Júnior; B.N. Meireles \& A.C.D. Santana. 2007. Macroinvertebrados bentônicos como bioindicadores de qualidade ambiental de corpos aquáticos da Caatinga. Oecologia Brasiliensis 11 (3): 397-409.

Aburaya, F.H. \& C.T. Calil. 2007. Variação temporal de larvas de Chironomidae (Diptera) no alto Rio Paraguai (Cáceres, Mato Grosso, Brasil). Revista Brasileira de Zoologia 24 (3): 565-572.

Amorim, R.M.; A.L Henriques-Oliveira \& J.L. Nessimian. 2004. Distribuição espacial e temporal das larvas de Chironomidae (Insecta: Diptera) na seção ritral do rio Cascatinha, Nova Friburgo, Rio de Janeiro, Brasil. Lundiana 2: 119-127.

Andrew, N.R.; L. Rodgerson \& M. Dunlop. 2003. Variation in invertebrate-bryophyte community structure at different spatial scales along altitudinal gradients. Journal of Biogeography 30: 731-746.

Beisel J.N.; V. Philippe \& T. Sandra. 1998. Stream community structure in relation to spatial variation: the influence of mesohabitat characteristics. Hydrobiologia 389: 73-88.

Brinkhurst, R.O. \& M.R. Marchese.1989. Guia para la identificacion de oligoquetos aquáticos continetales de Sud y Centroamerica. Santa Fé, Asociación de Ciencias Naturales del Litoral, 207p.

Callisto, M.; P. Moreno \& F.A.R. Barbosa. 2001. Habitat diversity and benthic functional trophic groups at Serra do Cipó, Southeast Brazil. Revista Brasileira de Biologia 61 (2): 259-266.

Costa, C.; S. IDE \& C.E. SimONKA. 2006. Insetos Imaturos: Metamorfose e Identificação. Ribeirão Preto, Holos, 249p.

Costa, S.S. \& A.S. Melo. 2008. Beta diversity in stream macroinvertebrate assemblages: among-site and amongmicrohabitat components. Hydrobiologia 598: 131-138.

Crisci-Bispo, V.L.; P.C. Bispo \& C.G. Froehlich. 2007. Ephemeroptera, Plecoptera and Trichoptera assemblages in two Atlantic Rainforest streams, Southeastern Brasil. Revista Brasileira de Zoologia 24 (2): 312-318.

Deacon, J.R.; N.E. Spahr; S.V. Mize \& R.W. Boulger. 2001. Using water, bryophytes, and macroinvertebrates to assess trace element concentrations in the Upper Colorado River Basin. Hydrobiologia 455: 29-39.

FERnÁndeZ, H.R. \& E. Domínguez. 2001. Guía para la determinacíon de los artrópodos bentónicos sudamericanos. San Miguel de Tucumán, Editorial Universitaria de Tucumán, 282p. 
Fidelis, L.H.; J.L. Nessimian \& N. Hamada. 2008. Distribuição espacial de insetos aquáticos em igarapés de pequena ordem na Amazônia Central. Acta Amazonica 38 (1): 127-134.

Flecker, A. \& B. Feifarek. 1994. Disturbance and the temporal variability of invertebrate assemblages in two Andean streams. Freshwater Biology 31: 131-142.

Galdean, N.; M. Callisto \& F.A.R. Barbosa. 2001. Biodiversity of benthic macroinvertebrates in altitudinal lotic ecosystems of Serra do Cipó (MG - Brazil). Revista Brasileira de Biologia 61 (2): 239-248.

GoRnI, G.R. \& R.G. Alves. 2007. Naididae (Annelida, Oligochaeta) associated with briophytes in Brotas, State of São Paulo, Brazil. Revista Brasileira de Zoologia 24 (2): 518-519.

HabDija, I.; B.P. Habdija; R. Matonickin; M. Kucinic; I. Radanovic; M. Milisa \& Z. Minaljevic. 2004. Current velocity and food supply as factors affecting the composition of macroinvertebrates in bryophyte habitats in karst running water. Biologia Bratislava 59 (5): 577-593.

HeINo, J. 2005. Functional biodiversity of macroinvertebrate assemblages along major ecological gradients of boreal headwater streams. Freshwater Biology 50: 1578-1587.

Heino, J. \& R. Virtanen. 2006. Relationships between distribution and abundance vary with spatial scale and ecological group in stream bryophytes. Freshwater Biology 51: 1879-1889.

KoRsu, K. 2004. Response of benthic invertebrates to disturbance from stream restoration: the importance of bryophytes. Hydrobiologia 523: 37-45.

KIKUCHI, R.M \& V.S. UiedA. 1998. Composição da comunidade de invertebrados de um ambiente lótico tropical e sua variação espacial e temporal, p. 153-173. In: J.L. Nessimian \& A.L. Carvalho (Eds). Ecologia de Insetos Aquáticos. Rio de Janeiro, PPGE-UFRJ, Série Oecologia Brasiliensis.

KownACKI, A. 1971. Taxocens of Chironomidae in streams of the Polish high Tatra Mts. Acta Hydrobiologica 13 (4): 439-464.

MagurRan, A.E. 2004. Measuring biological diversity. Oxford, Blackwell Publishing, 256p.

Martinelui, L.A. \& A.V. Krusche. 2007. Amostragem em rios, p. 263279. In: C.E.M. Bicudo \& D.C. Bicudo (Orgs). Amostragem em
Limnologia. São Carlos: RiMa, $2^{\text {nd }}$ ed., 351p.

McCAFferty, W.P. 1981. Aquatic Entomology. Boston, Jones and Bartlett Publishers, 448p.

McCafferty, P.W. \& A.V. Provonsha. 1983. Aquatic Entomology. Boston, Jones and Bartlett Publishers, $2^{\text {nd }}$ ed., 448p.

Merrit, R.W. \& K.W Cummins. 1984. An introduction to the Aquatic Insects of North America. Dubuque, Kendall/Hunt Publishing, 772p.

MotTA, R.L. \& V.S. Uieda. 2004. Diet and trophic groups of an aquatic insect community in a tropical stream. Brazilian Journal of Biology 64 (4): 809-817.

Pes, A.M.O.; N. Hamada \& J.L Nessimian. 2005. Chaves de identificação de larvas para famílias e gêneros de Trichoptera (Insecta) da Amazônia Central, Brasil. Revista Brasileira de Entomologia 49 (2): 181-204.

Roque F.O.; S. Trivinho-Strixino; L.A. Milan \& J.G. Leite. 2007. Chironomid species richness in low order streams in Brazilian Atlantic Forest: a first approximation through Bayesian approach. Journal of the North American Benthological Society 26: 221-231.

SousA, B.M. 2008. Plano de Manejo da Reserva Biológica Municipal Poço D'Anta, Juiz de Fora-MG. Juiz de Fora, Arcellor Mitral Juiz de Fora, AGENDA JF, IEF, 322p.

SuREN, A.M. 1991. Bryophytes as invertebrate habitat in two New Zealand alpine streams. Freshwater Biology 26: 399-418.

SuREN, A.M. 1993. Bryophytes and associated invertebrates in first-order alpine streams of Arthur's Pass, New Zealand. New Zealand Journal of Marine and Freshwater Research 27: 479-494.

Suriano, M.T. \& A.A. Fonseca-Gessner. 2004. Chironomidae (Diptera) larvae in streams of Parque Estadual de Campos do Jordão, São Paulo State, Brazil. Acta Limnologica Brasiliensia 16: 129-136.

TuRetsky, M.R. 2003.The role of bryophytes in carbon and nitrogen cycling. The Bryologist 106 (3): 3995-409.

Verdonschot, P.F.M.; M. Smies \& A.B.J. Sepers. 1982. The distribution of aquatic oligochaetes in brackish inland waters in the SW Netherlands. Hydrobiologia 89: 29-38.

Submitted: 03.V.2010; Accepted: 27.II.2011.

Editorial responsibility: Adriano S. Melo 